\title{
Discoidin domain receptor 1 functions in axon extension of cerebellar granule neurons
}

\author{
Rupal S. Bhatt, Toshifumi Tomoda, Yin Fang, and Mary E. Hatten ${ }^{1}$ \\ Laboratory of Developmental Neurobiology, The Rockefeller University, New York, New York 10021-6399 USA
}

In the developing cerebellum, granule neuron axon outgrowth is a key step toward establishing proper connections with Purkinje neurons, the principal output neuron of the cerebellum. During a search for genes that function in this process, we identified a receptor tyrosine kinase discoidin domain receptor 1 (DDR1) expressed in granule cells throughout their development. Overexpression of a dominant-negative form of DDR1 in immature granule cells results in severe reduction of neurite outgrowth in vitro, in dissociated primary culture, and in vivo, in organotypic slices of neonatal cerebellum. Granule cells that fail to extend axons are positive for differentiation markers such as TAG-1 and the neuron-specific class III $\beta$-tubulin, suggesting that development is affected after granule cells commit to terminal differentiation. DDR1 activation appears to be mediated by its ligand, collagen, which is localized to the pial layer of the developing cerebellum, thereby leading to granule cell parallel fiber extension. Our results therefore indicate that collagen-DDR1 signaling is essential for granule neuron axon formation and further suggest a unique role of pia in cerebellar cortex histogenesis.

[Key Words: DDR; collagen; parallel fiber; axon extension; cerebellar granule neuron; retrovirus]

Received May 25, 2000; revised version accepted July 7, 2000.

The synaptic connections among cerebellar cortical neurons are critical to the control of motor coordination and balance (Eccles et al. 1967; Brooks and Thach 1981) and have recently been implicated in aspects of cognitive processing involved in these events (Fiez 1996; Gao et al. 1996). These cerebellar functions develop as the five principal neuronal cell types, among which the granule neurons represent the largest population in the cerebellum, interconnect in a precise and coordinated manner (Eccles et al. 1967). Granule cells receive afferent input from mossy fibers, one of the major inputs into the cerebellum, and send output signals via parallel fibers that synapse with the dendritic arbors of Purkinje cells. Parallel fibers of the granule cells form just after the granule cell progenitors exit the cell cycle, as the first step in a program of neuronal differentiation (Ramon y Cajal 1995). Although the important roles of the granule cells in adult cerebellar function are well appreciated, how the formation of parallel fibers is regulated in the developing cerebellum remains largely unknown.

During cerebellar development, the granule cells arise in an unusual scheme with proliferating precursors positioned in a displaced germinal zone called the external germinal layer (EGL) just beneath the outer pial surface.

${ }^{1}$ Corresponding author.

E-MAIL hatten@rockvax.rockefeller.edu; FAX (212) 327-7140.

Article and publication are at www.genesdev.org/cgi/doi/10.1101/ gad.821600.
Molecular biological studies have subdivided this zone into an overlying layer of proliferating cells and an underlying layer of differentiating neurons that extend axons, the parallel fibers. In the deeper layer of the EGL, postmitotic cells begin to express genes that mark neuronal differentiation such as NeuroD (Lee et al. 1995), proteins that mark axon extension such as the axonal glycoprotein TAG-1 (Furley et al. 1990), and the neuronspecific $\beta$-tubulin isotype class III (for reviews, see Hatten and Heintz 1995; Hatten et al. 1997). These granule cell precursors follow further steps of differentiation as they migrate from the deeper EGL through the molecular layer (ML) toward the internal granular layer (IGL), where they form synaptic connection with ascending mossy fibers. The parallel fibers of the granule cells remain in ML where they synapse with the developing arbors of the Purkinje cell dendrites. Molecular studies provide evidence that a nonoverlapping pattern of gene expression is characteristic of the development of granule cells (Kuhar et al. 1993). Although much is known about the genes that mark each step of granule cell development such as proliferation and migration, the molecular mechanisms that signal the progression from proliferative status to parallel fiber extension remain unknown.

Recently, two novel receptor tyrosine kinases (RTKs), DDR1 and DDR2, were identified. These genes share a motif that has homology to the discoidin-I protein of the slime mold Dictyostelium discoideum in their extracel- 
lular domain (Vogel 1999). This sequence of $\sim 160$ amino acids (the discoidin homology domain) is also found in several other extracellular proteins. These include the blood coagulation factors V and VIII (Wood et al. 1984; Jenny and Mann 1989); neuropilin, a receptor component for semaphorins and for certain isoforms of vascular endothelial growth factor (He and Tessier-Lavigne 1997; Soker et al. 1998); and XLRS-1, a gene that when mutated causes human X-linked inherited disease retinoschisis resulting in retinal deterioration (Sauer et al. 1997). It has been shown that, in discoidin-I-deficient $D$. discoideum, cells lose their ability to adhere and migrate on the substratum, resulting in a defect in ordered cell aggregation (Springer et al. 1984).

Several types of collagen have been identified as candidate ligands for DDRs (Shrivastava et al. 1997; Vogel et al. 1997). Unlike most other RTKs, activation of DDRs follows unusually slow kinetics, taking up to $18 \mathrm{hr}$ to achieve maximum receptor autophosphorylation. The mouse DDR1 has been shown to be expressed in proliferating neuroepithelia (Zerlin et al. 1993). To date, no biological functions of DDRs have been demonstrated in the developing CNS.

Here, we provide the first evidence that DDR1 signals the initiation and/or maintenance of granule cell axon extension in the developing cerebellum, probably through collagen signaling. DDR1 is expressed throughout granule cell development, and multiple types of collagens are localized to the pia adjacent to the outer EGL of the cerebellum. We have tested DDR1 function both in in vitro and in vivo culture systems and shown that the dominant-negative inhibition of DDR1 function results in failure of the extension of bipolar axons/parallel fibers of the developing granule cells but does not appear to inhibit the commitment of granule cells to differentiation. Thus, DDR1 function reveals a novel intermediate stage of granule cell differentiation, subsequent to proliferation and early differentiation but prior to morphological differentiation to a process-bearing neuron.

\section{Results}

\section{DDR1 is highly expressed in the developing cerbellum}

To identify RTKs expressed in the developing cerebellum, a PCR-based screen was performed. Degenerate primers corresponding to highly conserved regions of the RTK catalytic domain (Hanks et al. 1988) were designed based on previously described screens (Lai and Lemke 1991) and used to amplify cDNAs from postnatal day (P)6 mouse cerebellum (see Materials and Methods). At this stage, a large population of granule neurons is poised to exit the cell cycle and initiate axon extension. Among 16 RTK clones amplified, we identified the mouse DDR1. During mouse embryogenesis, DDR1 is found as early as embryonic day (E)8, predominantly in the developing neuroectoderm (Zerlin et al. 1993). The DDR1 gene encodes two distinct protein isoforms ( $\mathrm{a}$ and $\mathrm{b}$ ) as a result of an alternative splicing, and DDR1b has an additional sequence of 37 amino acids in the juxtamem- brane region that contains an LXNPXY motif (Alves et al. 1995). Upon receptor activation, the tyrosine within this motif becomes phosphorylated and provides a binding site for Shc (Vogel et al. 1997). By RT-PCR analysis, we found that both DDR1a and DDR1b are equally expressed in the developing cerebellum (data not shown). The extensive homology $(-75 \%)$ of discoidin homology domain of DDR1 to the discoidin-I protein of the slime mold as well as a role of discoidin-I protein during the cell aggregation process led us to investigate the role of DDR1 during mammalian CNS development.

To provide a detailed expression pattern of DDR1, we performed Northern analysis. As reported previously (Zerlin et al. 1993), we found a single transcript of $4 \mathrm{~kb}$. Expression was detected in the CNS including the olfactory bulb, hippocampus, and cerebral cortex and in purified cerebellar granule cells, as well as in the lung, kidney, and weakly in the heart (Fig. 1E). A developmental profile of DDR1 expression was also analyzed using RNA from embryonic heads and a series of embryonic and postnatal cerebella. DDR1 is highly expressed in the developing cerebellum, and expression levels appear to be uniform throughout the course of development from embryonic stages to the adulthood (Fig. 1F).

In situ hybridization on sections from postnatal brains indicates DDR1 expression in the three regions of secondary (postnatal) neurogenesis: the olfactory bulb, the dentate gyrus of the hippocampal formation, and the cerebellum (Fig. 1A). Expression is also found in the rostral migratory stream leading to the olfactory bulb, in the Islands of Calleja, and diffusely in the cerebral cortex. Within the developing cerebellar cortex, DDR1 expression is detected in the EGL, the ML, and the IGL (Fig. 1B). In the adult, expression is detected in the IGL and in scattered cells in the ML (Fig. 1C). Expression is also present in the dentate gyrus of the hippocampal formation throughout development (Fig. 1D). We also examined the protein localization of DDR1 by immunohistochemistry using an antibody to DDR1 $(\alpha \mathrm{Cak}$, Santa Cruz). At P6, the protein, like the RNA, is expressed throughout all three layers of the cerebellar cortex (data not shown).

\section{The ligand of DDR1 is predominantly localized to the pia of the cerebellum}

The broad expression pattern of DDR 1 in the cerebellum led us to examine the temporal and spatial expression of its ligand. To localize the ligand for DDR1 in the developing cerebellum, we stained freshly frozen, nonfixed brain sections using a DDR1-Fc fusion protein that contained the extracellular domain of DDR1 fused in-frame with the Fc portion of human IgG1. Similar fusion proteins have been used to localize ligands in other studies of membrane bound receptors (Davis et al. 1994; Peles et al. 1997). At P0, DDR1-Fc bound specifically to the outer surface of the cerebellum (Fig. 2A). At P6, when the cerebellar folia are prominent, DDR1-Fc staining was seen along the pial surface of the folia (Fig. 2B), and similar binding was also detected in the adult cerebellum (Fig. 

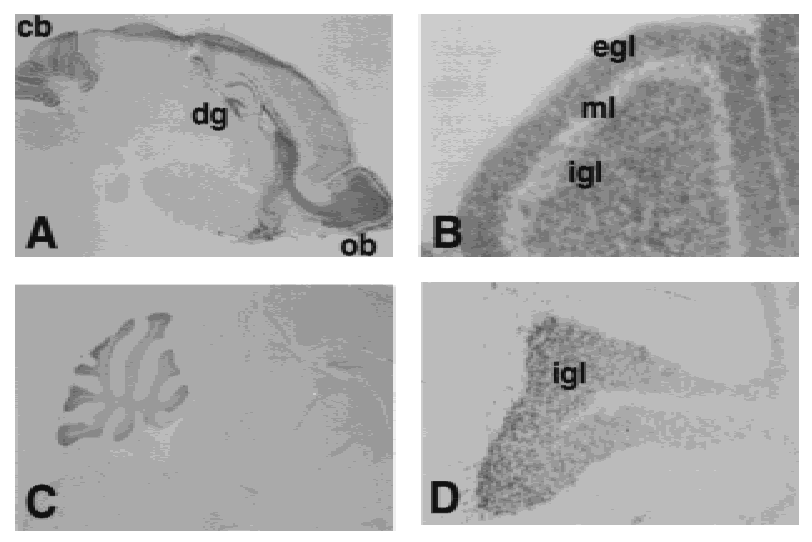

E

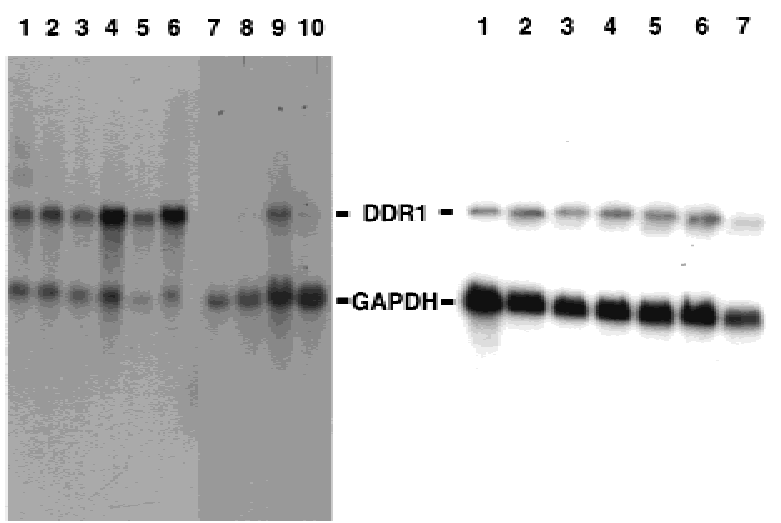

Figure 1. DDR1 is expressed in the developing CNS. DDR1 mRNA is detected in parasagittal sections of P6 $(A, B)$ and adult $(C, D)$ mouse brain by in situ hybridization. Labeled cells are seen in the cerebellum, dentate gyrus of the hippocampal formation, rostral migratory stream, olfactory bulb, and weakly in the cortex at P6 $(A)$ and in the cerebellum and dentate gyrus of the hippocampal formation in the adult $(C)$. At higher magnification of a cerebellar folium, expression is seen in the EGL, the $\mathrm{ML}$, and the IGL at P6 $(B)$ and in the IGL as well as in scattered cells in the ML in the adult $(D)$. $(E)$ Northern analysis detects DDR1 in total RNAs $(10 \mu \mathrm{g} /$ lane) from various tissues at P6. (Lane 1) Olfactory bulb; (lane 2) hippocampus; (lane 3) cerebral cortex; (lane 4) cerebellum; (lane 5) purified cerebellar granule cells; (lane 6) lung; (lane 7) spleen; (lane 8) liver; (lane 9) kidney; (lane 10) heart. GAPDH is used as a control for RNA levels. $(F)$ Steady levels of DDR1 signal are detected in whole brain at embryonic stages: (lane 1) E10.5; (lane 2) E12.5; and also in cerebellum throughout its developmental stages: (lane 3) E14; (lane 4) E17; (lane 5) P0; (lane 6) P6; (lane 7) P10.

2C). No background staining was observed using a control supernatant containing a secreted version of Fc protein alone. The same specific ligand localization was confirmed using DDR1-AP, another fusion protein containing DDR1 ectodomain fused with a human placental alkaline phosphatase (PLAP) (data not shown), further confirming the binding specificity of the DDR1 extracellular domain.

Collagen has recently been shown to be a ligand for the human DDR1 (Shrivastava et al. 1997; Vogel et al. 1997).
Using antibodies against collagens and sections serially adjacent to those used in Figure 2A-C, we found that collagen I (data not shown) and collagen IV (Fig. 2D-F) are localized to the pia of the cerebellum throughout the stages of the cerebellar development, a pattern similar to that achieved with DDR1-Fc. The data implies that the collagens are a major ligand of DDR1 in the developing cerebellum.

We detected collagen expression in a highly localized manner, whereas its receptor DDR 1 is expressed in all layers of the cerebellum. The fact that collagen is a secreted protein suggested that some collagen might escape detection as a result of diffusion during staining. Therefore, we prepared heavily fixed sections to immobilize collagens (see Materials and Methods) and stained them with a collagen antibody. Under these conditions, we detected a predominant expression of collagens in the pial cells as well as weaker graded collagen expression, highest at the pia and decreasing toward deeper layers of the cerebellar cortex (Fig. 2G). This is consistent with the idea that the collagens are produced and secreted from pial fibroblasts and diffuse to other regions of the cerebellum where they may continue signaling to DDR1 expressed in granule cells of the ML or IGL.

\section{Forms of truncated DDR1 function as dominant- negative reagents of the collagen-DDR1 signaling}

It is well established that RTKs that lack intracellular catalytic domains function as dominant-negative proteins by oligomerizing with endogenously expressed wild-type kinases and competing for ligand (Pawson and Scott 1997). To test whether this is the case with DDR1, we generated a construct encoding DDR1 $1 \Delta$, which lacks the intracellular catalytic domain of the DDR1, and transfected into 293T cells together with an expression construct encoding FLAG-tagged full-length wild-type DDR1b. The cells were then stimulated with collagens for $2 \mathrm{hr}$. The DDR1 protein was tyrosine phosphorylated by collagen in a dose-dependent manner as has been shown previously (Shrivastava et al. 1997; Vogel et al. 1997), and this autophosphorylation was greatly inhibited by coexpression of DDR1 $1 \Delta$ (Fig. 3, lane 3). These results suggest that the DDR $1 \Delta$ can function as a dominant-negative reagent for DDR1 kinase signaling when overexpressed in cells that endogenously express DDR1.

We also tested whether DDR1-Fc could function as a dominant-negative reagent by transfecting the fulllength wild-type DDR 1 into $293 \mathrm{~T}$ cells together with an expression construct expressing either DDR $1-\mathrm{Fc}$ or ssFc, a secretable form of the Fc protein. As shown in Figure 3 (lanes 4,5), whereas the ssFc protein did not affect autophosphorylation of the receptor, inclusion of the DDR1Fc in the culture media greatly down-regulated receptor autophosphorylation, indicating that DDR1-Fc is also a dominant-negative reagent. This data is consistent with a recent report, demonstrating that DDR2 receptor activation is efficiently suppressed by recombinant DDR2 extracellular domains (Vogel et al. 2000). 

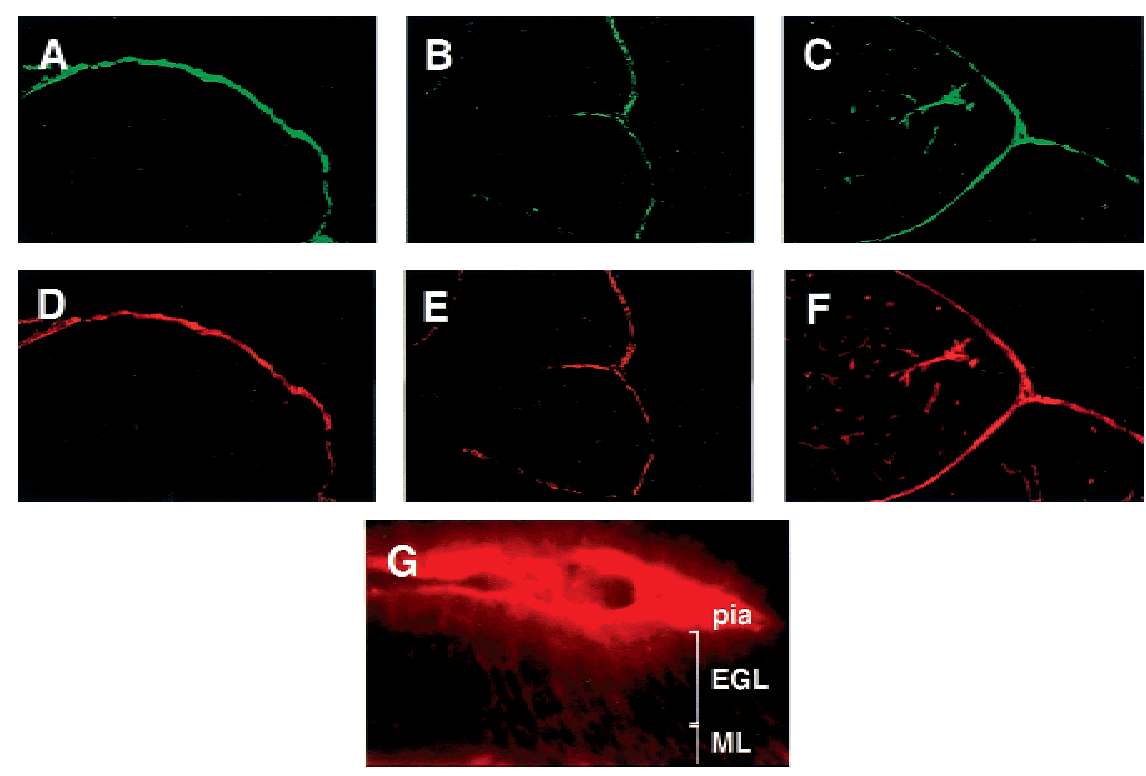

Figure 2. The ligand of DDR 1 and collagen IV are colocalized to the cerebellar pial surface. Immunofluorescent staining using DDR1-Fc $(A-C)$ or an anti-collagen IV antibody $(D-F)$ on parasagittal sections of mouse cerebellum identified positive signals at the pial surface of the cerebellum. Serially adjacent sections were stained with DDR1-Fc or an anti-collagen IV antibody at $\mathrm{P} 0(A, D), \mathrm{P} 6(B, E)$, and adult $(C, F)$. In an adult stage, positive signal was also present in the blood vessels of the cerebellum. $(G)$ Graded localization of collagen IV from the pial surface detected on a P6 cerebellar sagittal section $(30 \mu \mathrm{m})$.

\section{Sustained activation of DDR1 after collagen stimulation}

Previous studies reported that DDR1 activation by collagen takes place over a prolonged period of time, reaching the maximum level of activation $90 \mathrm{~min}$ to $2 \mathrm{hr}$ after ligand stimulation in vitro (Shrivastava et al. 1997; Vogel et al. 1997). Because of the unusually slow kinetics of the receptor activation, we speculated that DDR1, once stimulated, remains active even in the absence, or in the presence of a small amount, of the ligand. To test this hypothesis, we transfected 293T cells with the DDR1 expression construct, stimulated cells with collagen for $2 \mathrm{hr}$, and then removed collagen from the culture media and further incubated cells for an additional $3 \mathrm{hr}$. As shown in Figure 3 (lane 6), DDR1 remains autophosphorylated, indicating that the receptor can be active a significant time after the removal of the ligand. This also suggests that collagen-DDR1 signaling pathway may still be active in the developing granule cells even after the cells detach from the pia that is the predominant source of the ligand.

\section{Inhibition of collagen-DDR1 signaling blocks granule cell neurite extension on the pial culture}

The localization of collagen to the pia suggests that when granule cells are in contact with the pia, collagen may signal granule cells through DDR1 receptors, thereby influencing the development of the granule cells. Granule cells within superficial EGL and adjacent to the pia are still proliferating and start parallel fiber extension and migration along radial glial fibers shortly after they detach from the pia. Therefore, there are two possible functions for collagen expression in the pia. The first could be to keep granule cells proliferating. The other possibility is that collagen primes granule cells to stop proliferating, so that they can start differentiation.

To address this, we developed a system where pial cells were cultured as a monolayer for up to 2 weeks. Under these conditions, cultured pial cells maintained a high level of expression of collagens, including collagen I and IV, throughout the culture period (data not shown). Granule neurons were purified from P5-P6 cerebellum, labeled with the lipophilic dye PKH26, and plated at a low density on top of the pial monolayer for $36 \mathrm{hr}$. The great majority of labeled neurons $(60 \%-70 \%)$ on pial cells extended long neurites $(50-100 \mu \mathrm{m}$; data not shown), indicating that primary pial cells are capable of supporting morphological differentiation of granule neurons. Granule cells in culture maintained endogenous DDR1 expression as evidenced by positive staining with an anti-DDR1 antibody ( $\alpha$ Cak) (data not shown).

To establish whether collagen-DDR1 signaling is responsible for this differentiation, we infected the pial culture with a recombinant retrovirus containing either ssFc or DDR1-Fc. Once the pial cells reached $90 \%$ confluency, we added purified granule cells to assay neurite extension. It was assumed that DDR1-Fc proteins secreted from pial cells could bind and block collagens on the pial cell surface as in the in vitro autophosphorylation assay (Fig. 3). Thirty-six hours after plating granule cells on pial cells expressing either ssFc or DDR1-Fc, cultures were fixed and neurite length was quantitated. Cultures were also stained for differentiation markers including Tuj-1, that recognizes a neuron-specific $\beta$-tubulin class III isotype (Przyborski and Cambray-Deakin 1997), or an anti-TAG-1, a marker for axonal glycoprotein (Furley et al. 1990; Gao et al. 1991). In control cultures with pial cells expressing ssFc, $>70 \%$ of the granule cells extended long processes $(50-80 \mu \mathrm{m})$, similar to those on the noninfected pial monolayer. In addition, almost all the granule neurons were Tuj- 1 positive, and $\sim 10 \%$ of the neurons were TAG-1 positive (Fig. 4B,D). However, in pial cultures expressing DDR1-Fc, granule cells extended shorter neurites (5-30 $\mu \mathrm{m})$, most of these truncated neurons were Tuj-1 positive, and $\sim 10 \%$ of 
Bhatt et al.
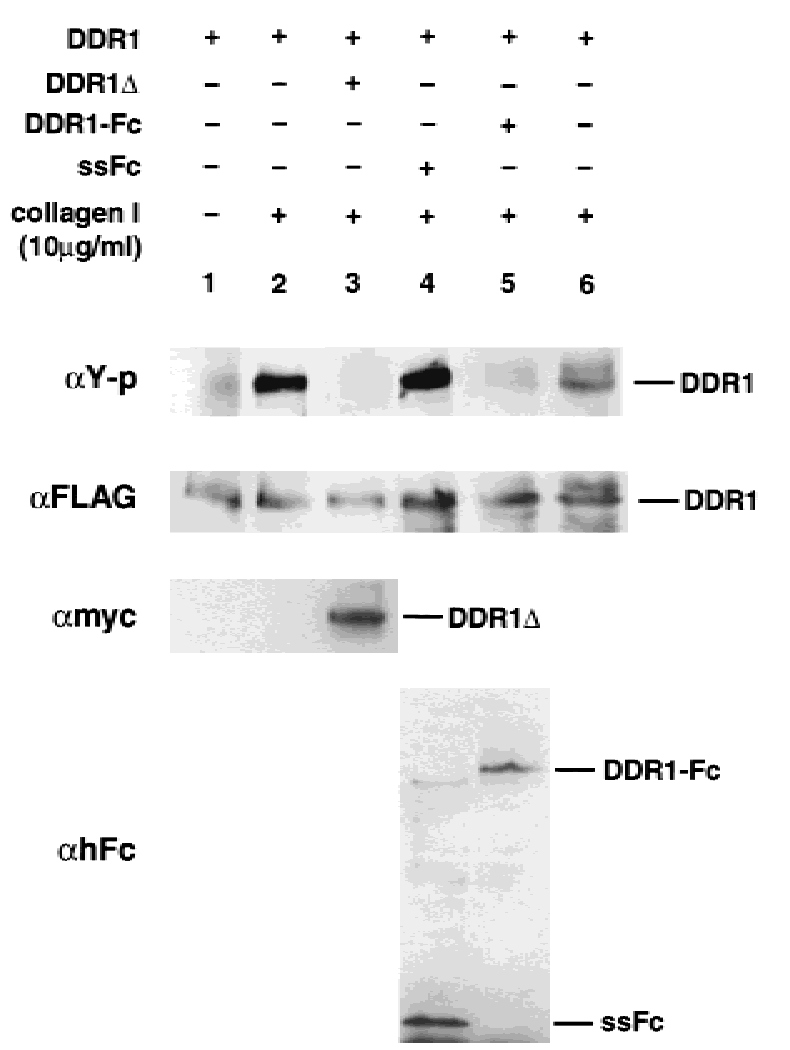

Figure 3. Coexpression of DDR1 $1 \Delta$ or DDR1-Fc with wild-type DDR1 down-regulates tyrosine phosphorylation of DDR 1 kinase. $293 \mathrm{~T}$ cells were transiently transfected with the FLAGtagged full-length wild-type DDR1 together with various expression constructs indicated. Eighteen hours after transfection, cells were serum-starved overnight and then stimulated with collagen I ( $10 \mu \mathrm{g} / \mathrm{ml})$ for $2 \mathrm{hr}$. Immunoblotting was performed using antibodies indicated. Lane 2 shows that DDR 1 was phosphorylated in the presence of collagen I. This phosphorylation was inhibited by the coexpression of DDR $1 \Delta$ (lane 3). Lanes 4 and 5 show that DDR1-Fc could also reduce phosphorylation of

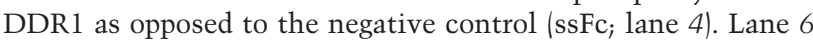
shows that phosphorylation persisted after collagens were removed from the culture supernatant, and the cells were further incubated for $3 \mathrm{hr}$ before harvesting.

those were TAG-1 positive (Fig. 4A,C). In parallel experiments, we measured the degree of granule cell proliferation on the pial monolayer by 5 -bromo-2'-deoxyuridine (BrdU) labeling, to see if the truncated neurons remain in the cell cycle. We detected no granule cells incorporating BrdU on the pial cells expressing either ssFc or DDR1-Fc (data not shown), suggesting that the granule cells did not remain in the cell cycle. These results indicate that the disruption of collagen-DDR1 signaling specifically blocked granule cell neurite extension after the cells committed to terminal differentiation.

\section{Collagen does not change the proliferative status of cerebellar granule cells}

To further address the issue of whether collagen promotes granule cell proliferation, we purified granule cells, incubated them with varying concentrations of collagens (either soluble or immobilized on the substrate), and pulse-labeled them with tritiated thymidine. As shown in Figure 5, granule cells treated with increasing amounts of collagen showed no alteration in their proliferative status in our culture conditions. In a control experiment with the same culture condition, $100 \mathrm{~nm}$ of Sonic Hedgehog (SHH), a known potent mitogen for granule cells (Wechsler-Reya and Scott 1999), displayed a fivefold increase in thymidine incorporation of the granule cells (data not shown). These results suggest that the collagen signaling does not promote proliferation of granule cells.

\section{Expression of a dominant-negative DDR1 reduces granule cell neurite elongation in vitro}

To further assess the requirement for DDR1 in granule cell development, we investigated the effect of overexpressing a dominant-negative DDR $1(\mathrm{DDR} 1 \Delta)$ in granule cells. cDNA encoding a wild-type DDR1 or DDR1 $1 \Delta$ was subcloned into a retroviral vector pLIA (a gift from Laura Lillien, University of Pittsburgh, PA) that contains an internal ribosomal entry site-alkaline phosphatase (IRES-AP) cassette to facilitate visualization of infected cells by a simple colorimetric assay. Recombinant retroviruses were subsequently used to infect immature granule cells purified from P5-P6 cerebellum, and cells were kept in high-density conditions on poly-L-lysine and Matrigel-coated dishes. Thirty-six to $48 \mathrm{hr}$ after infection, AP color reaction revealed well-isolated, individual infected cells that could be visualized in the context of a large number of uninfected cells. Under these conditions, $80 \%-90 \%$ of the cells infected either with the control virus (pLIA) that expresses only AP or with the virus expressing wild-type DDR1 (DDR1.wt/LIA) extended long neurites (50-200 $\mu \mathrm{m}$; Fig. 6A,B). In contrast, when cells were infected with DDR $1 \Delta /$ LIA, significantly fewer cells $(32 \pm 6.7 \%)$ extended long neurites (longer than three cell-body diameters) when compared with the normalized wild-type situation (Fig. 6C,D). The majority of cells infected with DDR1 $\Delta /$ LIA either had no processes or had short processes (less than three cell-body diameters). Thus, expression of dominant-negative DDR1, but not wild-type kinase, reduced granule cell neurite elongation.

\section{DDR1 is necessary for the elongation of granule cell parallel fibers in situ}

We have shown that DDR1 functions in granule cell neurite formation in vitro. However, the question remained whether the gene functions in the intact, developing cerebellum where other cell types might influence granule cell behaviors. To address this question, we devised a method to deliver wild-type or dominant-negative forms of DDR1 into granule cell precursors developing in situ within thick brain slices (Tomoda et al. 1999|. Coronal slices were prepared from P8 cerebellum and infected with DDR1 $\Delta /$ LIA, DDR1.wt/LIA, or pLIA. 

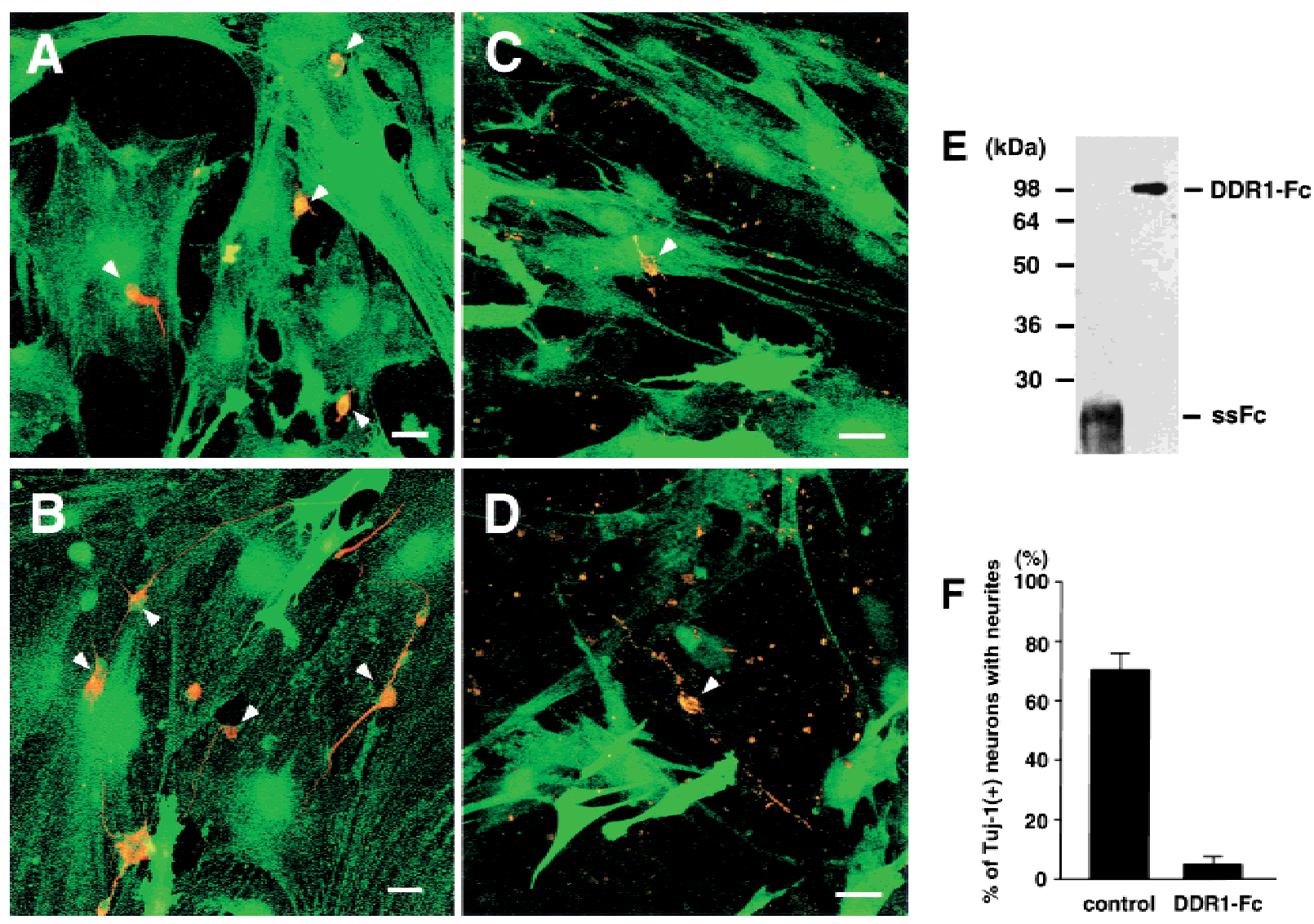

Figure 4. A soluble form of DDR1 functions dominant negatively in neurite extension of granule cells cultured on pial cells. Granule cells were placed at a low density on a pial monolayer expressing either DDR $1-F c(A, C)$ or ssFc $(B, D)$ and cultured for 36 hr. Pial cells infected with GFP viruses expressing recombinant Fc-fusion proteins were visualized by GFP epifluorescence, confirming that almost all pial cells express a uniform level of fusion proteins. After fixation, granule cells (red) were visualized by antibody staining using either Tuj-1 $(A, B)$ or anti-TAG-1 antibody $(C, D)$ with a Cy-3 conjugated secondary antibody. Fewer granule cells extended neurites in the presence of DDR1-Fc, as opposed to in the presence of ssFc. Arrowheads indicate granule cells positive for antibody staining. Expression of recombinant $\mathrm{Fc}$-fusion proteins in the pial culture supernatant was confirmed by immunoblotting using an anti-human IgG1-Fc antibody $(E)$. DDR1-Fc migrated at $98 \mathrm{kD}$, and the ssFc migrated at $27 \mathrm{kD}$. $(F)$ The percentage of Tuj-1-positive granule cells with neurites $>20 \mu \mathrm{m}$ in length, placed on the pial monolayer expressing either DDR $1-\mathrm{Fc}(5 \pm 2 \%)$ or ssFc $(70 \pm 6 \%)$, was scored. Scale bars, $10 \mu \mathrm{m}$ in $A, B$ and $20 \mu \mathrm{m}$ in $C, D$.

Granule cell precursors are preferentially infected because they are actively proliferating near the surface of the cerebellum at this stage. Because our previous studies using dye-labeling techniques demonstrated that the granule cell precursors in EGL require 36-72 hr to exit the cell cycle, extend parallel fibers, and further migrate inward along Bergmann glial fibers (Gao and Hatten 1994), we cultured the slices over this period of time and observed parallel fiber elongation.

The granule cell precursors on slices infected with pLIA either extended long bipolar axons or adopted the T-shaped morphology, which is characteristic of migrating, differentiated granule neurons (Fig. 7B,C). On the other hand, the majority of granule cells infected with DDR $1 \Delta /$ LIA failed to extend bipolar axons longer than three cell-body diameters (Fig. 7A). Whereas $78 \%$ of the cells infected with the control virus extended parallel fibers $>100 \mu \mathrm{m}$, only $44 \%$ of the cells infected with DDR1 $\Delta /$ LIA possessed parallel fibers (Fig. 7D). Thus, the findings of the slice culture experiment, together with the results from dissociated cell cultures, provide strong evidence that DDR1 functions in the formation of granule cell neurites/parallel fibers.

\section{Discussion}

In the present study we identified mouse DDR1 during a screen for kinases expressed in the developing cerebellum and demonstrated that the gene functions in granule neuron neurite elongation. DDR1 is a member of the discoidin domain receptor tyrosine kinases that have been shown to bind to, and be activated by, multiple collagens (Shrivastava et al. 1997; Vogel et al. 1997). DDR1 is expressed in cerebellar granule cells throughout their development. Dominant inhibition of the DDR1 kinase activity resulted in severe truncation of neurite extension of dissociated granule cells in culture and also of granule cells developing in situ. Furthermore, our 
Bhatt et al.
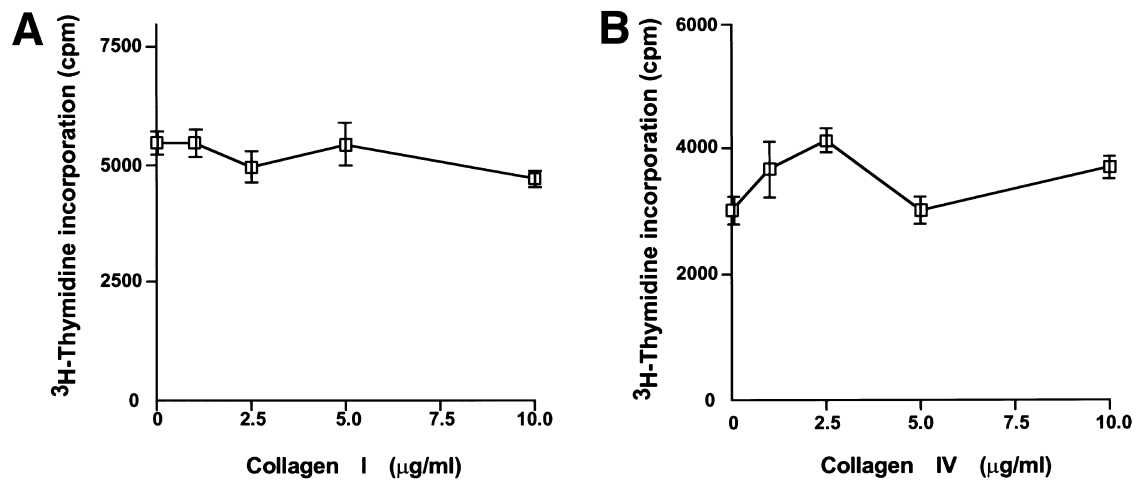

Figure 5. Collagen does not affect the proliferative status of granule cells. $(A, B)$ Granule cells were purified and cultured in a 96-well microtiter plate with indicated amounts of collagen I or IV for $48 \mathrm{hr}$. The culture was pulsed with $\left[{ }^{3} \mathrm{H}\right]$ thymidine for the last $12 \mathrm{hr}$, and incorporated counts were measured by a scintillation counter. $(C, D)$ Granule cells were also cultured on a microtiter plate precoated with indicated amounts of collagen I or collagen IV, and thymidine incorporation was measured. Increasing amounts of collagen I and IV, either soluble or immobilized, did not affect the proliferative status of the granule cells.
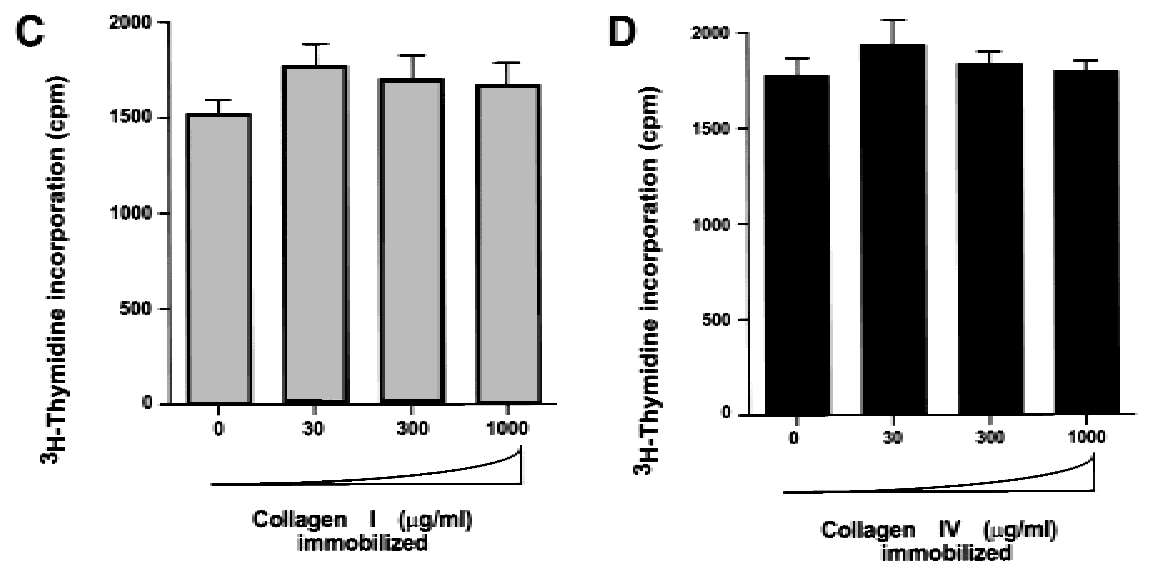

marker studies have demonstrated that the gene appears to function specifically in neurite elongation without affecting the granule cells' commitment to differentiation. Taken together, our results have, for the first time, assigned a role for DDR1 in process formation, a key step in establishing circuitry in the cerebellum.

\section{Expression of collagen and DDR1 in murine CNS development}

Our results confirm the widespread expression of DDR1 in the CNS and underscore its role in cerebellar development. In the postnatal cerebellar cortex, expression was detected within all layers throughout the stages of development. Therefore, DDR1 may have roles other than axon extension at later stages, such as maintenance of process structure, regulation of synapse formation, and process sprouting. Furthermore, in the case of olfactory precursor neurons in the rostral migratory stream that are actively migrating without extending axons (Lois et al. 1996), DDR1 may be involved in regulation of migration. Thus, it will be interesting to assess the precise expression pattern of collagen, a ligand of DDR1, and to test and further define the role of this gene during olfactory neuron development.

In our attempt to identify ligands of DDR1 using a DDR1-Fc fusion protein as a probe, we found that the spatiotemporal pattern of DDR1-Fc binding activity closely overlaps with collagen expression during cerebellar development. This implies that collagen is the major ligand of DDR1 in developing cerebellum, consistent with the previous biochemical purification of collagen as a DDR ligand (Shrivastava et al. 1997; Vogel et al. 1997). However, our data does not necessarily rule out the possibility that DDR1 has another, yet unidentified, ligand that may have a low affinity to DDR1 or may be present in low abundance or may require coreceptors other than DDR1 for high-affinity binding to the receptor complex.

It is notable that the DDR1 protein is ubiquitously expressed in developing granule cells both in the EGL and IGL, whereas its ligand collagen is primarily expressed in pial fibroblasts. It is therefore possible that the second ligand for DDR1 is present as discussed above and is capable of signaling DDR1 in granule cells after they detach from the pial surface. An alternative possibility is that, once exposed to collagen, DDR1 undergoes prolonged autophosphorylation and may no longer require sustained contact with collagens or require only small amounts of collagens to keep its activation, which could lead to continuous parallel fiber formation of granule cells. This is consistent with our findings that collagens appear to be secreted to form a gradient over the cerebellar cortex and that DDR1 displays sustained autophosphorylation in vitro even after removal of collagen.

\section{DDR1 functions in granule cell axon extension in vitro and in vivo}

We have presented the first indication of DDR function in mammalian CNS development. The conclusion that 

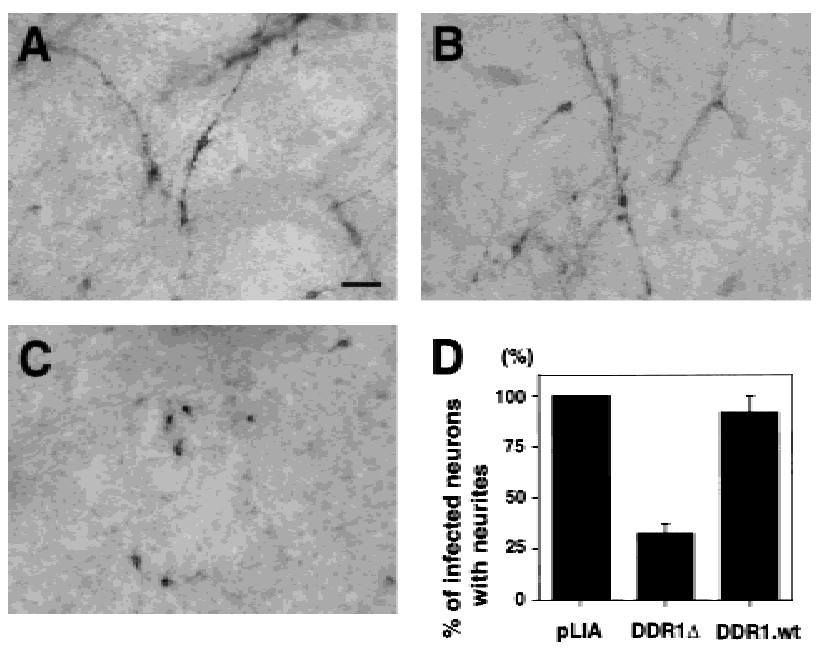

Figure 6. Expression of dominant-negative DDR1 inhibits neurite extension of granule cells in culture. P6 cerebellar granule cells extend neurites when infected with pLIA $(A)$ or with wild-type DDR1 $(B)$. When retrovirus expressing DDR1 $\Delta$ was used, infected granule cells did not extend neurites $(C)$. Granule cells with processes longer than three cell-body lengths were scored as neurite-harboring cells. The effect was quantitated in the graph $(D)$. The experiment was performed seven times, and the number of cells with versus the number of cells without neurites were counted. The averages were normalized to the pLIA control. As compared with pLIA $(100 \%)$, DDR $1 \Delta$ decreased neurite outgrowth to $32 \pm 6.7 \%$, and the wild-type virus did not decrease neurite outgrowth $(91 \pm 9 \%)(P=0.0032$ in a paired $t$-test). Scale bar, $50 \mu \mathrm{m}$.

DDR1 functions in granule cell neurite formation is based on the finding that dominant inhibition of kinase activity results in inhibition of neurite growth both in vitro and in vivo. The finding in vivo that overexpression of a dominant-negative form of the gene in granule cells within the EGL resulted in disruption of the parallel fibers provides strong evidence for a role for DDR1 in parallel fiber formation in vivo. Although the majority of neurons overexpressing DDR $1 \Delta$ had truncated axons, we consistently observed a considerable percentage of dominant-negative infected granule cells with long neurites. It is possible that these neurons had initiated neurite extension before exogenous dominant-negative proteins accumulated to levels adequate to counteract endogenous DDR1 activity. Alternatively, these results may reflect positional effects of the insertion of the retroviral vector in granule cells.

Although the dominant inhibition of the DDR1 kinase resulted in neurite truncation, the affected cells were positive for differentiation markers such as Tuj-1. Therefore, they did not appear to stay longer in the cell cycle nor did they fail to commit to terminal differentiation. Rather, the dominant-negative DDR1 appears to specifically affect the elongation of neurites. This findings contrast with our recent data, showing that the dominant inhibition of function of another gene, Unc51.1, also caused severe neurite truncation of granule cells but also failure in expression of differentiation markers such as
TAG-1 and Tuj-1 (Tomoda et al. 1999). Thus, DDR1 seems to function downstream of Unc51.1, or the two genes may function independently in neurite elongation in separate signaling pathways.

Recently, overexpression of a dominant-negative DDR1 in the myoblast cell line $\mathrm{C} 2 \mathrm{C} 12$ has been shown to block cellular differentiation (Vogel et al. 2000). Cells expressing a dominant-negative DDR1 failed to form multinucleated, elongated myotubes, whereas a parental
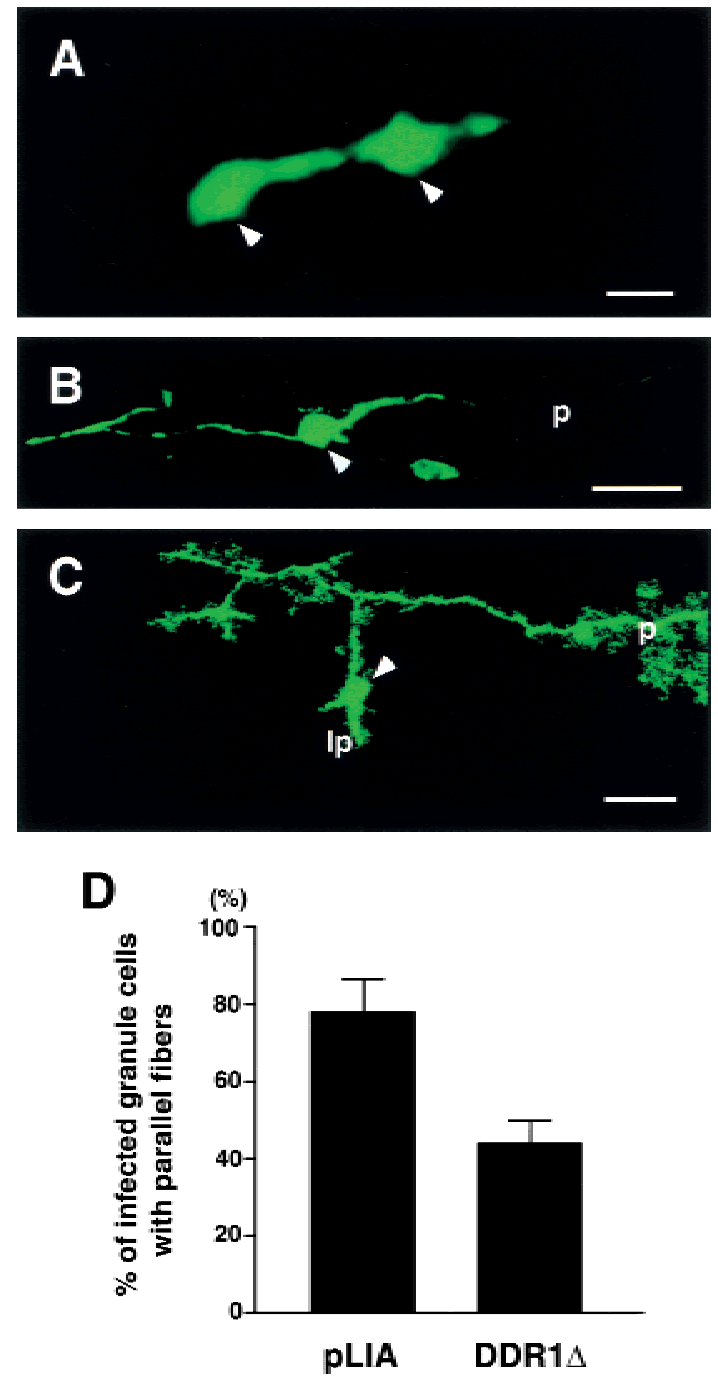

Figure 7. Expression of dominant-negative DDR1 inhibits parallel fiber extension of granule cells developing in situ. Coronal slices of P8 cerebellum were infected either with pLIA or with DDR1 $\Delta /$ LIA. Thirty-six to $72 \mathrm{hr}$ later, parallel fibers were visualized by confocal microscopy after an anti-AP antibody staining. (A) Granule cells (arrowheads) infected with DDR1 $\Delta /$ LIA are seen with truncated axons. $(B)$ A cell infected with pLIA extends long bipolar axons (p). (C) Another cell (arrowhead) infected with pLIA migrates inward along glial fibers, revealing a T-shaped parallel fiber (p) with a leading process (lp). The percentages of neurons with parallel fibers were scored $(D)$. Infection of DDR1 $\Delta$ reduced the numbers of granule cells with parallel fibers (pLIA $=78 \pm 7 \%$, DDR $1 \Delta=44 \pm 5 \%, n=4, P=0.01$ by a $t$-test). Scale bars, $10 \mu \mathrm{m}$ in $A$ and $20 \mu \mathrm{m}$ in $B, C$. 
cell line responded to collagen-DDR1 signaling by fusion to myotubes. Consistent with these findings, we have observed that collagen-DDR1 signaling is responsible for the dramatic morphological differentiation of primary neurons characterized by axon formation. Thus, the molecular basis of the DDR1 function might be to regulate the intracellular cytoskeletal components such as actin and microtubules required for these morphological changes.

Although we have shown that collagen-DDR1 signaling is necessary for neurite formation, our previous data also suggest that this pathway is not sufficient to drive neurite extension of cerebellar granule cells. For example, granule cells cultured on a dish coated with collagen are incapable of extending axons. In contrast, laminin provides a permissive environment for the neurite extension of the cerebellar granule cells in culture (Bhatt et al., unpubl.). Thus, there must be other essential factors present in vivo that initiate neurite outgrowth and function in further neurite elongation in concert with the collagen-DDR1 signaling pathway.

\section{Biochemical basis for DDR1 function}

It has been shown that DDR1 is unique in that the activation of the kinase requires up to $18 \mathrm{hr}$ to reach maximal tyrosine kinase activity (Shrivastava et al. 1997; Vogel et al. 1997, 1999). In the present study we have further shown that the DDR1 kinase remains active even after the removal of the ligand in a cell culture system. This is striking because most RTKs such as an epidermal growth factor receptor (EGFR) and platelet-derived growth factor receptor (PDGFR) are rapidly inactivated soon after the removal of the ligand (Pawson and Scott 1997). This may underlie the basis of how the DDR 1 kinase expressed on the granule cells could remain active even after the cells detach from the pia, the primary source of the collagen ligand. It is possible that DDR1, once activated, could remain phosphorylated for a long period of time. Alternatively, we have noted a graded, low level of collagen in the EGL and ML, possibly by diffusion from pia, and thus DDR1 may be responding to this low concentration of ligand in those regions of the cerebellum.

The DDR1 protein is known to be partially processed into a $63-\mathrm{kD}$ membrane-anchored subunit and a soluble 54-kD subunit by as yet unidentified protease (Alves et al. 1995). There is a putative protease recognition sequence RXRR found in the extracellular domain of DDR1. It is noteworthy that the latter soluble subunit may be able to function as a dominant-negative protein in vivo, as we have shown with our recombinant fusion protein DDR1-Fc, consisting of the DDR1 extracellular domain and the human IgG1 Fc region. This post-translational protein processing mechanism using a protease may be the way the DDR1 controls its own activity in vivo.

\section{Role of pia in cerebellar development}

It has long been postulated that cerebellar pial cells provide a signal to granule cells in the EGL during develop- ment, but the means by which the pia exerts such effects has not been clear. Electron microscopic studies demonstrated that cells in the outer EGL maintain close contacts with the pia (Hausmann and Sievers 1985). Studies in which the drug 6-hydroxydopamine (6-OHDA) has been used to chemically eliminate the pial cells have implicated the pia as playing a role in cerebellar fissuration, lamination, and granule cell proliferation (Sievers et al. 1981; Pehlemann et al. 1985). In our coculture system, the pia appears to be important for granule cell neurite extension, with pial collagen and DDR1 in granule cells appearing to play a significant role in this process.

It is not surprising that the pial cells have multiple and complex roles such as proliferation, process extension, and migration. In our pia-neuron coculture experiments, we found that granule cells can extend long neurites; however, the degree of extension was significantly less than those cultured on a dish coated with Matrigel or laminin, which is a highly permissive condition for granule cell neurite outgrowth (Bhatt et al., unpubl.). Moreover, granule cells cultured on pia appeared to either rapidly turn off TAG-1 or cleave TAG-1 proteins from the cell surface by an unknown mechanism. This might be the reason why we saw fewer numbers of TAG-1-positive cells than those of Tuj-1-positive cells on the pial cultures expressing both Fc-fusion proteins. In our culture condition, we believe that the overall activity of the pial cells is to support differentiation of granule cells.

\section{Role of collagen-DDR1 signaling pathway during cerebellar granule cell development}

The spatiotemporal program of granule cell development is a hallmark of cerebellar histogenesis. The finding that collagen in the pial membrane provides a ligand to promote differentiation suggests that the pia sets forth the initial organization of the EGL during cerebellar histogenesis. Within the EGL, proliferating precursor cells are adjacent to the pia. Our data argues for DDR1-mediated signaling to induce the next step of granule cell development, neurite extension. Cells undergoing this step are located just deep to the zone of cells along the pia. A number of markers identify these cells as undergoing axon extension, including the axonal glycoproteins TAG-1 and L1 (for review, see Hatten and Heintz 1995). As the parallel fibers grow to lengths of several hundred microns, the cell soma commences migration along the glial fibers. During the first phase of parallel fiber extension, granule cell neurites are patterned parallel to the pial surface that, in turn, sets forth the topographic organization of their interaction with growing Purkinje cell dendrites. The expression of DDR1 in granule cells at all stages of development, together with the ligand localized to the pial surface, therefore provides a template for granule cell axon patterning.

These results also provide, for the first time, an example of a receptor-ligand interaction in the context of a pial-neuronal interaction and also present evidence of a biological function of DDR1 in cerebellar development. These functional studies of DDR1 may aid the analysis 
of this molecule in other systems, as well as contribute to a better understanding of the molecular mechanisms of cerebellar development. It will be important, in the future, to elucidate the steps in the signaling pathway of DDR1 to understand better the mechanism by which it exerts its biological function.

\section{Materials and methods}

\section{PCR-based RTK screen and Northern blot}

Degenerate PCR primers corresponding to highly conserved sequences (DLAA/TRN in kinase subdomain VI and DVWSF/LG in kinase subdomain IX) of the catalytic domain of RTKs were designed as described previously (Lai and Lemke 1991). The degenerate oligonucleotides used were $5^{\prime}-\mathrm{GA}(\mathrm{T} / \mathrm{C}) \mathrm{CTX}$ GCX (A/G)CX CGX AA-3' as a sense primer and $5^{\prime}$-CC XA/A/G) XGA CCA XAC $(\mathrm{A} / \mathrm{G}) \mathrm{TC}-3^{\prime}$ as an antisense primer, where $\mathrm{X}$ indicates complete degeneracy. RNA extracted from purified P6 cerebellar granule cells was used as a template. Cycling parameters of PCR were as follows: $94^{\circ} \mathrm{C}$ for $45 \mathrm{sec}, 40^{\circ} \mathrm{C}$ for $3 \mathrm{~min}$, and $72^{\circ} \mathrm{C}$ for $2 \mathrm{~min}$ for the first 3 cycles and $94^{\circ} \mathrm{C}$ for $45 \mathrm{sec}, 54^{\circ} \mathrm{C}$ for $3 \mathrm{~min}$, and $72^{\circ} \mathrm{C}$ for $2 \mathrm{~min}$ for the next 37 cycles. Of 34 clones obtained, 16 were aligned with known RTK sequences by BLAST search (National Center for Biotechnology Information), which included focal adhesion kinase (FAK), glial cell line-derived neurotrophic factor receptor (GDNFR/c-ret), hepatocyte growth factor receptor (HGFR/c-met), Janus kinase 1 and 2 (JAK1, JAK2), and DDR1. An amplified sequence corresponding to DDR1 was used to screen a mouse P6 cerebellar cDNA library, and several overlapping clones were obtained. Of those, one clone contained a $1.2-\mathrm{kb}$ insert that includes the 3 '-untranslated region (UTR) of DDR1 (nucleotides 2490-3659) and was used as a probe for Northern blot. Ten micrograms of total RNA isolated from various tissues was loaded per lane of $1 \%$ agaroseformaldehyde gel, and blotting and hybridization were performed according to the standard procedure.

\section{In situ hybridization}

In situ hybridization was performed essentially as described (Schaeren-Wiemers and Gerfin-Moser 1993) on fresh frozen, sagittal sections fixed for $30 \mathrm{~min}$ in $4 \%$ paraformaldehyde and infused with $30 \%$ sucrose before cryosectioning at $10 \mu \mathrm{m}$. Digoxigenin-labeled probes were prepared from the $1.2 \mathrm{~kb} \mathrm{3'}$ UTR sequence used in Northern blot according to the manufacturer's instructions (Boehringer Mannheim) and used with 200-400 ng/ $\mathrm{ml}$ final concentration. Signals were detected with an alkaline phosphatase-conjugated goat anti-digoxigenin $\mathrm{F}\left(\mathrm{ab}^{\prime}\right)$ antibody and subsequent colorimetric assays using NBT $(0.33 \mathrm{mg} / \mathrm{ml})$ and BCIP $(0.17 \mathrm{mg} / \mathrm{ml})$ (Boehringer Mannheim). No nonspecific background signal was detected using the sense probe, ensuring the specificity of the signal detected by the antisense probe.

\section{Plasmid construction}

The expression construct for the full-length wild-type mouse DDR1 (a gift from Marielba Zerlin; Zerlin et al. 1993) is as described (pCMV-NEP-myc ${ }^{3}$; Vogel et al. 1997). We also added a FLAG at the carboxyl terminus of full-length wild-type DDR1 and cloned it into pcDNA3 (Invitrogen) to generate pcDNA3DDR1-FLAG for use in immunoblot experiments. DDR1-Fc was constructed as follows: the DDR1 ectodomain was amplified by PCR using a pair of oligonucleotides, 5'-CCGAATTC-
CAGAGCGATGGGGACAGGGACC-3' (sense) and 5'-CCGGATCCGAGCCGCTCCCCTCCGCCTTGCC-3' (antisense), and digested with EcoRI and BamHI. The Fc portion of a human IgG1 was excised with BamHI and XbaI from pBSKS-hFc (a gift from Takeshi Sakurai, NYU Medical Center, New York). Two fragments were ligated so that the DDR1 ectodomain fused inframe with the Fc. The junction contained a GSGS sequence that helps avoid potential steric hindrance. DDR1-AP was also constructed essentially in the same way using the APtag2 vector (a gift from John Flanagan, Harvard Medical School, Boston, MA) to excise an AP portion with BgIII and HpaI. ssFc was amplified by PCR from an ssFc expression construct ( $\mathrm{pEF}-\mathrm{ssFc}$; a gift from Ming Guo, Rockefeller University, New York) and subcloned in pcDNA3 (Invitrogen). DDR1 $1 \Delta$ was constructed by amplifying the carboxy-terminal portion of the cDNA (pCMVNEP-myc ${ }^{3}$ ) by PCR using the SP6 primer (in MCS) and the following primer: 5'-GGCCTCGAGCCTTCCTGGCGGATGATGCG-3' and digesting the resulting product with XhoI and EcoRV. The PCR product was subcloned into pcDNA3-DDR1FLAG, which was digested with NotI, filled in with Klenow, and digested with $X$ hoI, to generate pcDNA3-DDR $1 \Delta-\mathrm{myc}^{3}$. For retroviral expression constructs, DDR1-Fc and ssFc were subcloned in the GFP retrovirus vector (described in Tomoda et al. 1999) to generate DDR1-Fc-IRES-GFP and ssFc-IRES-GFP constructs, respectively. These constructs allowed us to visualize infected pial cells by green epifluorescence. The full-length wild-type DDR1-myc ${ }^{3}$ and DDR $1 \Delta-\mathrm{myc}^{3}$ were subcloned in the pLIA vector (a gift from L. Lillien; Lillien 1995), which includes an EMCV IRES and a heat-stable human PLAP to facilitate visualization of infected cells by a simple colorimetric reaction.

\section{Immunoblot}

Immunoblot on whole-cell lysate was done essentially as described (Vogel et al. 1997, 2000). Briefly, the FLAG-tagged wildtype DDR1 expression construct $(1.5 \mu \mathrm{g})$ as well as expression constructs containing either DDR1-Fc, ssFc, or DDR $1 \Delta-\mathrm{myc}^{3}$ $(4.5 \mu \mathrm{g})$ were transiently transfected in $293 \mathrm{~T}$ cells by the standard calcium-phosphate transfection protocol. Eighteen hours after transfection, cells were serum-starved overnight, stimulated with collagen I $(10 \mu \mathrm{g} / \mathrm{ml})$ for $2 \mathrm{hr}$, and then lysed in $\mathrm{TNE}_{150}$ buffer (150 mM NaCl, $50 \mathrm{~mm}$ Tris-Cl at $\mathrm{pH} 7.4,1 \mathrm{~mm}$ EDTA) containing $1 \%$ Triton X-100, 1 mm phenylmethylsulfonyl fluoride, and $1 \mathrm{~mm}$ sodium orthovanadate. The detergent soluble fraction was recovered by centrifugation, loaded on $10 \%$ SDS-polyacrylamide gel, subjected to electrophoresis (SDSPAGE), and transferred onto a nitrocellulose membrane. The blot was probed with an anti-phosphotyrosine monoclonal antibody (1:1000, 4G10, Upstate Biotechnology, NY). The same amount of samples were loaded on a parallel gel, blotted, and probed with an anti-FLAG monoclonal antibody (M2, Kodak) to ensure equal DDR1 expression or with an anti-myc monoclonal antibody (9E10, Oncogene Research) to confirm DDR $1 \Delta-\mathrm{myc}^{3}$ expression.

For detection of DDR1-Fc or ssFc, $25 \mu \mathrm{l}$ of the culture supernatant was loaded on $10 \%$ SDS-PAGE, and immunoblot was performed using an anti-human IgG1-Fc monoclonal antibodyHRP conjugated (1:5000, Zymed).

Tyrosine phosphorylation upon collagen stimulation was observed only when DDR1-FLAG cDNA was transfected, confirming the identity of tyrosine phosphorylated bands as DDR1. Identity of tyrosine phosphorylated bands were further confirmed by immunoprecipitation with M2 followed by probing with 4G10 (data not shown). 


\section{Retrovirus production}

Recombinant ecotropic replication-incompetent retroviruses were produced as described (Tomoda et al. 1999). Briefly, 293 cells were transiently transfected with one of the retrovirus expression constructs together with pCL-Eco, an ecotropic packaging construct (IMGEN; Naviaux et al. 1996). Twentyfour hours after transfection, media was replaced with the granule cell media (Hatten 1985), and the culture supernatant containing the retroviruses was harvested $24 \mathrm{hr}$ and $48 \mathrm{hr}$ later and filtered through a 0.45 - $\mathrm{mm}$ pore. Virus titers were estimated by infecting NIH-3T3 cells with virus supernatants with serial dilution. Typically, the titers ranged from $4 \times 10^{5}$ to $1 \times 10^{7}$ $\mathrm{cfu} / \mathrm{ml}$.

\section{Primary cultures of pial fibroblasts and granule cells}

To prepare pial cultures, meninges were collected from cerebella of five P4-P6 mice, dissociated in $0.5 \%$ trypsin-DNase, and cultured on a noncoated plastic dish ( $35 \mathrm{~mm}$ diam.) in granule cell media until the cells formed a confluent monolayer ( 4 days). The cells were then trypsinized and further subcultured on a 4-well glass chamber (Nunc) precoated with poly-L-lysine (Sigma) and Matrigel (Becton Dickinson). Infection with DDR1Fc or ssFc viruses was initiated after the cells settled on the glass surface. Once the culture reached $90 \%$ of confluency, dissociated granule cells were prepared as described below and sprinkled over the pial culture at a low density $\left(5 \times 10^{4} /\right.$ well $)$. PKH26 labeling was as described (Gao et al. 1994). The mixed culture was incubated for $36 \mathrm{hr}$, fixed in $4 \%$ paraformaldehyde in phosphate-buffered saline (PBS; $\mathrm{pH} 7.4$ ), and subjected for immunocytochemistry as described below.

Granule cells were prepared as described (Hatten 1985). Granule cell media (Basal Media Eagle supplemented with 10\% horse serum, $5 \%$ fetal bovine serum, $2 \mathrm{~mm} \mathrm{~L}$-glutamine, $50 \mathrm{U} / \mathrm{ml}$ penicilllin, $50 \mu \mathrm{g} / \mathrm{ml}$ streptomycin, and $9.5 \mathrm{~mm}$ glucose) was used in most of the experiments except for the thymidine incorporation assay, in which serum-free media [Neurobasal media supplemented with $100 \mu \mathrm{g} / \mathrm{ml}$ albumin, B-27 supplement (1:50 diluted), $50 \mathrm{U} / \mathrm{ml}$ penicillin, and $50 \mu \mathrm{g} / \mathrm{ml}$ streptomycin] was used. For BrdU labeling of the granule cells, $10 \mu \mathrm{g} / \mathrm{ml}$ of BrdU (Amersham) was included in the culture media 6-12 hr after granule cells were added to the pial cells. By the time the BrdU was added to the culture, pial fibroblasts had ceased their proliferation as a result of contact inhibition and did not incorporate BrdU.

\section{Thymidine incorporation assay}

Proliferation assays using tritiated thymidine (NEN Life Science) were performed as described (Gao et al. 1991). Briefly, granule cells purified from P5-P6 mice were cultured on a 96well microtiter plate at a $3 \times 10^{5} /$ well density in serum-free media supplemented with varying amounts of collagen I (Sigma C-7661) or collagen IV (Sigma C-0543) for $48 \mathrm{hr}$. Alternatively, cells were placed on a 96-well plate precoated with varying amounts of collagen I or IV $(0-1000 \mu \mathrm{g} / \mathrm{ml})$. $\left[{ }^{3} \mathrm{H}\right]$ Thymidine was included for the last $18 \mathrm{hr}$ of culture period. The cells were harvested and blotted on the glass filter paper (Wallac) using the Harvester 96 Mach III M (TOMTEC), and then the trapped radioactivity was measured by a scintillation counter. Recombinant SHH protein (R\&D systems) was used at $100 \mathrm{~nm}$ as a positive control.

\section{Infection of primary cerebellar granule cells in vitro}

Retroviral infection of granule cells was performed essentially as described (Tomoda et al. 1999). In brief, dissociated granule cells purified from P5-P6 C57BL/6J mice were plated at a high density $\left(2 \times 10^{6} /\right.$ well $)$ in an uncoated 16-well Lab-Tek glass chamber (Nunc) and infected with recombinant retroviruses overnight. After $18-24 \mathrm{hr}$, the cultures were gently resuspended at $1 \times 10^{6}$ cells $/ \mathrm{ml}$, plated in Lab-Tek slides coated with polyL-lysine and Matrigel, cultured for an additional 36-48 hr to allow granule cell neurite elongation, and then fixed for AP colorimetric reaction. Expression of transgenes (DDR1-myc ${ }^{3}$ and DDR $1 \Delta-$ myc $^{3}$ ) was confirmed by antibody staining (9E10) (data not shown).

\section{Preparation and infection of organotypic cerebellar slices}

Organotypic cerebellar slices were prepared according to the procedure described by Stoppini et al. (1991) with minor modifications (Tomoda et al. 1999). To visualize parallel fibers on the slices, cerebella isolated from P6-P8 mice were chopped coronally 250-300 $\mu \mathrm{m}$ thick by a McILWAIN Tissue Chopper (Brinkmann), and slices were maintained on a tissue culture insert (Millicell, Millipore) that is submerged in slice culture media [Basal Media Eagle at pH 7.4 supplemented with $10 \mu \mathrm{g} / \mathrm{ml}$ BSA (Sigma, A-9418), 2 mM L-glutamine, 0.5\% glucose, $1 \times$ ITS supplement (Sigma, I-1884), $50 \mathrm{U} / \mathrm{ml}$ penicillin, and $50 \mu \mathrm{g} / \mathrm{ml}$ streptomycin]. Two hours after dissection, virus infection was initiated. Thirty-six to $72 \mathrm{hr}$ after the start of virus infection, slices were fixed and processed for immunocytochemistry.

\section{Immunocytochemistry}

Antibody staining was performed essentially as described (Gao et al. 1991). The dilutions of antibodies used were anti-Cak antibody (polyclonal, 1:100), anti-mouse collagen I antibody (monoclonal, Sigma, C-2456, 1:100), anti-mouse collagen IV antibody (monoclonal, Sigma, C-1926, 1:100), anti-TAG-1 antibody (monoclonal, IgM, 4D7, 1:2), anti-class III $\beta$-tubulin antibody (monoclonal, IgG2a, Tuj-1, 1:7500; Babco), and anti-BrdU antibody (monoclonal, IgG2a, 1:1; Amersham). Specimens were viewed either with epifluorescent illumination (Axiophot 100 microscope, Zeiss) or with an MRC-600 confocal microscope (Bio-Rad). For immobilization of extracellular matrix molecules including collagens, animals were perfused with $4 \%$ paraformaldehyde in PBS, and dissected brains were heavily fixed in $1 \%$ glutaraldehyde plus $4 \%$ paraformaldehyde overnight at $4^{\circ} \mathrm{C}$ and then incubated in 30\% sucrose-PBS overnight additionally.

For detection and morphological assessment of infected cells in dissociated culture by AP colorimetric reaction, cells were fixed in $4 \%$ paraformaldehyde and incubated at $65^{\circ} \mathrm{C}$ for $90 \mathrm{~min}$ to heat-inactivate endogenous alkaline phosphatase activity. The cells were then incubated in AP buffer $(100 \mathrm{~mm} \mathrm{NaCl}, 100$ $\mathrm{mM}$ Tris- $\mathrm{Cl}$ at $\mathrm{pH} 9.5,50 \mathrm{~mm} \mathrm{MgCl}_{2}$ ) containing $0.33 \mathrm{mg} / \mathrm{ml}$ $\mathrm{NBT}, 0.17 \mathrm{mg} / \mathrm{ml} \mathrm{BCIP}$, and $0.24 \mathrm{mg} / \mathrm{ml}$ levamisole at room temperature overnight and mounted.

For detection of infected granule cells on slices, Tyramide signal amplification (TSA) system (NEN Life Science) was used with a rabbit anti-human PLAP antibody (Zymed, 1:1000), according to the manufacturer's instructions, and the slices were observed with the confocal microscopy.

For DDR1-Fc staining, thin sagittal sections $(10 \mu \mathrm{m})$ prepared from fresh frozen brains were rinsed once with the binding buffer (Hank's balanced salt solution supplemented with $10 \mu \mathrm{g} /$ $\mathrm{ml} \mathrm{BSA}$ ), incubated at room temperature for $90 \mathrm{~min}$ in the culture supernatant of $293 \mathrm{~T}$ cells transfected with DDR1-Fc expression plasmid, washed four times with the binding buffer, postfixed in $4 \%$ paraformaldehyde-PBS, and detected with a FITC-conjugated rabbit anti-human IgG1-Fc specific antibody (1:100, Pierce). 


\section{Acknowledgments}

We are grateful to Betsy Ross for providing us with an antibody, Marielba Zerlin for providing expression constructs, Dillon Patterson for his help with in situ hybridizations, Nick Didkovsky for confocal image rendering, Niels Adams for advice and for critically reading the manuscript, David Solecki for insightful discussions, and Nat Heintz and Kathryn Zimmerman for criticism and valuable discussions. R.B. was supported by NIH MSTP grant GM07739. R.B. is a student in the Cornell/Rockefeller/Sloan-Kettering Tri-Institutional MD-PhD program. T.T. was supported in part by the Toyobo Biotechnology Foundation (Tokyo, Japan). This work was supported by Program Project PHS NS30532-05 (M.E.H.) and by the March of Dimes (\#1-FY99-510; M.E.H.).

The publication costs of this article were defrayed in part by payment of page charges. This article must therefore be hereby marked "advertisement" in accordance with 18 USC section 1734 solely to indicate this fact.

\section{References}

Alves, F., Vogel, W., Mossie, K., Millauer, B., Hofler, H., Ullrich, A. 1995. Distinct structural characteristics of discoidin I subfamily receptor tyrosine kinases and complementary expression in human cancer. Oncogene 10: 609-618.

Brooks, V.B., and Thach, W.T. 1981. Section 1: The nervous system, volume II. Motor control. In Handbook of physiology, (ed.V.B. Brooks), pp. 877-946. American Physiological Society, Bethesda, MD.

Davis, S., Gale, N.W., Aldrich, T.H., Maisonpierre, P.C., Lhotak, V., Pawson, T., Goldfarb, M., and Yancopoulos, G.D. 1994. Ligands for EPH-related receptor tyrosine kinases that require membrane attachment or clustering for activity. Science 266: 816-819.

Eccles, J.C., Ito, M., and Szentágothai, J. 1967. The cerebellum as a neuronal machine. Springer, New York, NY.

Fiez, J.A. 1996. Cerebellar contributions to cognition. Neuron 16: $13-15$.

Furley, A.J., Morton, S.B., Manalo, D., Karagogeos, D., Dodd, J., and Jessell, T.M. 1990. The axonal glycoprotein TAG-1 is an immunoglobulin superfamily member with neurite outgrowth-promoting activity. Cell 61: 157-170.

Gao, J.H., Parsons, L.M., Bower, J.M., Xiong, J., Li, J., and Fox, P.T. 1996. Cerebellum implicated in sensory acquisition and discrimination rather than motor control. Science 272: 545 547.

Gao, W.-Q., and Hatten, M.E. 1994. Immortalizing oncogenes subvert the establishment of granule cell identity in developing cerebellum. Development 120: 1059-1070.

Gao, W.-Q., Heintz, N., and Hatten, M.E. 1991. Cerebellar granule cell neurogenesis is regulated by cell-cell interactions in vitro. Neuron 6: 705-715.

Hanks, S.K., Quinn, A.M., and Hunter, T. 1988. The protein kinase family: Conserved features and deduced phylogeny of the catalytic domains. Science 241: 42-52.

Hatten, M.E. 1985. Neuronal regulation of astroglial morphology and proliferation in vitro. J. Cell Biol. 100: 384-396.

Hatten, M.E., and Heintz, N. 1995. Mechanisms of neural patterning and specification in the developing cerebellum. Annu. Rev. Neurosci. 18: 385-408.

Hatten, M.E., Alder, J., Zimmerman, K., and Heintz, N. 1997. Genes involved in cerebellar cell specification and differentiation. Curr. Opin. Neurobiol. 7: 40-47.

Hausmann, B., and Sievers, J. 1985. Cerebellar external granule cells are attached to the basal lamina from the onset of mi- gration up to the end of their proliferative activity. J. Comp. Neurol. 241: 50-62.

He, Z., and Tessier-Lavigne, M. 1997. Neuropilin is a receptor for the axonal chemorepellent semaphorin III. Cell 90: 739751.

Jenny, R.J., and Mann, K.G. 1989. Factor V: A prototype procofactor for vitamin K-dependent enzyme complexes in blood clotting. Baillieres Clin. Haematol. 2: 919-944.

Kuhar, S.G., Feng, L., Vidan, S., Ross, M.E., Hatten, M.E., and Heintz, N. 1993. Changing patterns of gene expression define four stages of cerebellar granule neuron differentiation. Development 117: 97-104.

Lai, C., and Lemke, G. 1991. An extended family of proteintyrosine kinase genes differentially expressed in the vertebrate nervous system. Neuron 6: 691-704.

Lee, J.E., Hollenberg, S.M., Snider, L., Turner, D.L., Lipnick, N., and Weintraub, H. 1995. Conversion of Xenopus ectoderm into neurons by NeuroD, a basic helix-loop-helix protein. Science 268: 836-844.

Lillien, L. 1995. Changes in retinal cell fate induced by overexpression of EGF receptor. Nature 377: 158-162.

Lois, C., Garcia-Verdugo, J.M., and Alvarez-Buylla, A. 1996. Chain migration of neuronal precursors. Science 271: 978981.

Naviaux, R.K., Costanzi, E., Haas, M., and Verma, I.M. 1996. The pCL vector system: Rapid production of helper-free, high-titer, recombinant retroviruses. J. Virol. 70: 5701-5705.

Pawson, T., and Scott, J. 1997. Signaling through scaffold, anchoring, and adapter proteins. Science 278: 2075-2080.

Pehlemann, F.-W., Sievers, J., and Berry, M. 1985. Meningeal cells are involved in foliation, lamination, and neurogenesis of the cerebellum: Evidence from 6-hydroxydopamine-induced destruction of meningeal cells. Dev. Biol. 110: 136146.

Peles, E., Nativ, M., Lustig, M., Schilling, J., Martinez, R., Plowman, G.D., Grumet, M., and Schlessinger, J. 1997. Identification of a novel contactin-associated transmembrane receptor with multiple domains implicated in protein-protein interactions. EMBO J. 16: 978-988.

Przyborski, S.A., and Cambray-Deakin, M.A. 1997. Profile of glutamylated tubulin expression during cerebellar granule cell development in vitro. Brain Res. Dev. Brain Res. 100: 133-138.

Ramon y Cajal, S. 1995. The cerebellum. In Histology of the nervous system of man and vertebrates (Translated by $\mathrm{N}$. Swanson and L.W. Swanson), pp. 3-123. Oxford University Press, New York, NY.

Sauer, C.G., Gehrig, A., Warneke-Wittstock, R., Marquardt, A., Ewing, C.C., Gibson, A., Lorenz, B., Jurklies, B., and Weber, B.H.F. 1997. Positional cloning of the gene associated with X-linked juvenile retinoschisis. Nat. Genet. 17: 164-170.

Schaeren-Wiemers, N., and Gerfin-Moser, A. 1993. A single protocol to detect transcripts of various types and expression levels in neural tissue and cultured cells: in situ hybridization using digoxigenin-labelled cRNA probes. Histochemistry 100: 431-440.

Shrivastava, A., Radziejewski, C., Campbell, E., Kovac, L., McGlynn, M., Ryan, T.E., Davis, S., Golfarb, M.P., Glass, D.J., Lemke, G., et al. 1997. An orphan receptor tyrosine kinase family whose members serve as non integrin collagen receptors. Mol. Cell 1: 25-34.

Sievers, J., Mangold, U., Berry, M., Allen, C., and Schlossberger, H.G. 1981. Experimental studies on cerebellar foliation. I. A qualitative morphological analysis of cerebellar fissuration defects after neonatal treatment with 6-OHDA in the rat. $J$. Comp. Neurol. 203: 751-769. 
Bhatt et al.

Soker, S., Takashima, S., Miao, H.Q., Neufeld, G., and Klagsbrun, M. 1998. Neuropilin-1 is expressed by endothelial and tumor cells as an isoform-specific receptor for vascular endothelial growth factor receptor. Cell 92: 735-745.

Springer, W.R., Cooper, D.N.W., and Barondes, S.H. 1984. Discoidin I is implicated in cell-substratum attachment and ordered cell migration of Dictyostelium discoideum and resembles fibronectin. Cell 39: 557-564.

Stoppini, L., Buchs, P.A., and Muller, D. 1991. A simple method for organotypic cultures of nervous tissue. J. Neurosci. Methods 37: 173-182.

Tomoda, T., Bhatt, R.S., Kuroyanagi, H., Shirasawa, T., and Hatten, M.E. 1999. A mouse serine/threonine kinase homologous to C. elegans UNC51 functions in parallel fiber formation of cerebellar granule neurons. Neuron 24: 833-846.

Vogel, W. 1999. Discoidin domain receptors: Structural relations and functional implications. FASEB J. 13: S77-S82.

Vogel, W., Gish, G.D., Alves, F., and Pawson, T. 1997. The discoidin domain receptor tyrosine kinases are activated by collagen. Mol. Cell 1: 13-23.

Vogel, W., Brakebusch, C., Fassler, R., Alves, F., Ruggiero, F., and Pawson, T. 2000. Discoidin domain receptor 1 is activated independently of $\beta 1$ integrin. J. Biol. Chem. 275: 57795784.

Wechsler-Reya, R.J., and Scott, M.P. 1999. Control of neuronal precursor proliferation in the cerebellum by Sonic Hedgehog. Neuron 22: 103-114.

Wood, W.I., Capon, D.J., Simonsen, C.C., Eaton, D.L., Gitschier, J., Keyt, B., Seeburg, P.H., Smith, D.H., Hollingshead, P., and Wion, K.L. 1984. Expression of active human factor VIII from recombinant DNA clones. Nature 393: 330-337.

Zerlin, M., Julius, M.A., and Goldfarb, M. 1993. NEP: A novel receptor-like tyrosine kinase expressed in proliferating neuroepithelia. Oncogene 8: 2731-2739. 


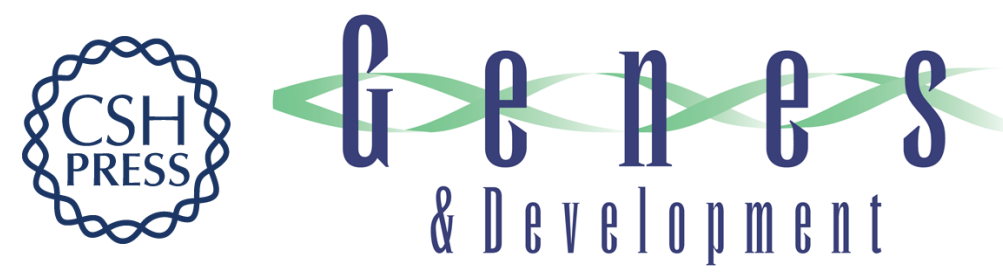

\section{Discoidin domain receptor 1 functions in axon extension of cerebellar granule neurons}

Rupal S. Bhatt, Toshifumi Tomoda, Yin Fang, et al.

Genes Dev. 2000, 14:

Access the most recent version at doi:10.1101/gad.821600

References This article cites 37 articles, 12 of which can be accessed free at: http://genesdev.cshlp.org/content/14/17/2216.full.html\#ref-list-1

License

Email Alerting

Receive free email alerts when new articles cite this article - sign up in the box at the top Service right corner of the article or click here.

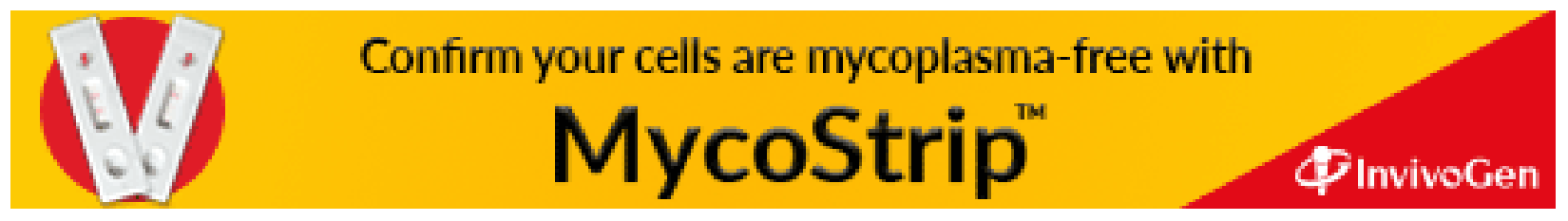

